\title{
新科目「歴史基礎」の特徴と 具体化に向けて
}

高橋昌明

\section{I ． 経過の説明}

現行の高校地理歴史科は、世界史の必修と、 日本史または地理から1科目の選択を義務づけ ている。一方、大学入試センター試験の地理歴 史は、一部の大学を除き1科目だけ受験すれば よく、授業時間数の縮減などもあって、世界史 の授業をしない高校が出現。2006年にはいわ ゆる未履修問題が表面化した。

その後、中央教育審議会高校部会では世界史 必修の維持を決めたが、未履修問題は何らの解 決も見ていない。一方、関東の自治体の一部に、 日本史必修を追加する動きが始まった。こうし た現状を打開するため、日本学術会議の高校地 理歴史教育に関する分科会では、高校に日本史 と世界史を統合する新科目（歴史基礎）を設置 するという方向で、歴史教育の改革の方途を模 索してきた。それにあたって参加メンバーには、 人や情報が国境を越えて盛んに行きかう時代 には、世界史・日本史ともに重要性は増してお り、どちらが必修にふさわしいかという二者択 一の態度はとらない、という共通認識があった。 この間分科会では、地歴科教育および関連す る諸問題を、精力的に議論してきた。そして、 2008 年 6 月 7 日に、「高校教育における時間と 空間認識の統合一世界史未履修問題をどう解 決するか一」(於東京大学教養学部)、20011年 4月 23 日には「新しい高校地理・歴史教育の創 造一グローバル化時代を生き抜くために一」(於
日本学術会議講堂）の、二度の公開シンポジウ ムを催した。そこで分科会の議論の状況や確認 点を紹介し、フロアからの発言も受け止めて問 題を掘り下げてきた。

筆者は二度のシンポジウムで、それぞれ「日 本史・世界史総合科目について一日本史の立場 から一」、「新科目『歴史基礎』の特徵と具体化 にむけて」を報告した。前者は『学術の動向』 （2008年10月号）にその内容が掲載されている が、分科会での議論がはじまったばかりだった ので、基本的には個人意見の表明にとどまって いる。

それに対し後者は、議論を続けてほぼ煮詰 まった段階での報告で、分科会の意見を代表す るものといってよい。ただ当日は時間の制約が あり、はしょった形でしか報告できなかったの で、本稿で若干の追加説明をほどこすことにし た。またその時点では、例示としての授業構成 案は、IVで紹介するA案に絞られた形だった。 その後、各方面の示唆によって、提言最終案で は、参考資料として $\mathrm{A} ・ \mathrm{~B} ・ \mathrm{C}$ の三案を併記し、 今後の議論の活発化を促すことになった。この 点がシンポジウム当日と大きく変わっている ことを明らかにしておきたい。

\section{II. 新科目「歴史基礎」の 基本的特徴とその具体化}

まず、これまでの歴史教育では世界史と日本 
史が分断されていたことが問題である。日本の 歴史が世界とほとんど関係を持たないという 理解は、日本の歴史研究全般や、大学において 日本史・東洋史・西洋史の三専攻が並立し歴史 教育もそれに則った縦割りで行われていると いう現状ともかかわるが、グローバル化時代を 生きる日本の若者にとって決して望ましいこ とではない。一方、世界史は日本を除いた各地 域の歴史一一中国史と西ヨーロッパ史が他に優 越する一一集合として教えられてきた。とく に近代以前においては、諸地域世界が並存する 形で叙述が進み、世界の一体化が進む近現代に なって、ようやく日本史と世界史の関連が指摘 される傾向が強かった。それ故、歴史基礎の新 設にあたっては、世界史の中に日本史を明確に 位置づける必要がある。

次に、歴史基礎は現世界史の必修にかわるべ き必履修科目として提案される。かつて世界史 が必修とされた理由は、世界史教育を通じての 国際性の涵養にあった。歴史基礎ではその継承 発展が求められる。そして世界史を通じて国際 性の涵養を図るには、従来のヨーロッパ中心の 叙述が克服されねばならない。歴史基礎では、 世界の様々な歴史主体の独自性や主体性を重 んじるとともに、その相互滲透を理解させる歴 史叙述が必要となる。国際性教育とは、(1)国際 社会の成立はそれぞれに個性をもった諸地域 が長い時間をかけて相互に交流し結合した結 果であることを認識させ、(2)すべての地域の個

\section{PROFILE}

高橋昌明

(たかはし まさあき)

日本学術会議連携会員、神戸大学名

誉教授

専門: 史学
性を等価値に扱って、諸地域への差別、偏見を 除去することにある。

第三に、歴史教育においては、歴史的知識の 教授と歴史的思考力の育成が、ともに重要であ るにもかかわらず、従来は圧倒的に前者に偏っ てきた。このため、歴史の授業は「知識の詰め 込み・暗記中心」と受け止められ、生徒の「歴 史嫌い・歴史離れ」を促進してきた。世界史が 未履修になった原因の一つも、大学受験に最も 多くの暗記努力を必要とする世界史が忌避さ れたところにある。

「歴史基礎」では、歴史的思考力の育成と歴 史的知識の教授とに同等の比重をおき、歴史を 「考える楽しみ」を味わえる教科に変えてゆく 必要がある。そのため、主題学習の充実をはか るとともに、生徒たちが考える面白さを味わえ るように工夫する。また、調べ学習、グループ 研究 - 発表 - 討論、資料 · 年表の収集 - 解読な どの機会を増加し、自発的な学習に導く。

以上はめざされるべき新科目「歴史基礎」の 基本的特徵であるが、日本史、世界史の統合が 求められるにもかかわらず、現行の地歴科内に おいては 2 単位（週 2 回、通年で70回）しか充 
てることができない。その時間の絶対的な制約 のもとでは、網羅的に世界史と日本史の通史を 教えることは不可能である。それ故、内容の厳 選と各時代の基本的な特徵や歴史的なものの 考え方を学ぶ主題学習との組み合わせが必要 である。世界史と日本史を統合する方法として は、（A）古代から現代までの時系列をべース とする型、（B）近現代史集中型、(C) 主題学 習中心型の三タイプが考えられる。

\section{III. 各タイプの基本的特徵}

以下、それぞれのタイプが備えるべき基本的 特徵を述べたい。

\section{$A$ 案：時系列型+主題学習型}

歴史教育においては系統的な歴史知識の教 授が必要である点を考慮して、古代から現代ま での時系列的な教育を基本とする。ただし、授 業時間数の制約を考え、網羅的に教えるのでは なく、項目を思い切って精選するとともに、主 題学習ともあいまって、各時代の特徵、平和 · 人権などの今日的な課題につながる事項を重 点的に教えるようにする。その際、従来の歴史 教育では日本史と世界史の間で時代区分や時 代の性格規定にズレがあった点の調整が必要 になる。これらを通じて世界各地域の歴史の独 自性、歴史的事実の解釈の多様性に気づかせる よう配慮する。

一方、項目の精選ともかかわるが、世界の各 地域の個性を等価值に扱いつつ、しかも「東ア
ジア地域」という場が、相対的に重視されるべ きである。それによって、前近代史においても 日本を世界史の一部として構造的に位置づけ ることが可能になるからである。それにあたり 参考になるのは、近年盛んになっている日本・ 韓国・中国などの間での歴史対話である。「東 アジア地域史」を媒介とする日本史と世界史の 結合には、歴史研究・歴史教育両面で参考に值 する成果が蓄積されてきていると言える。

\section{$B$ 案：近現代史集中型}

この案は、2 単位の範囲で生徒達が一応の歴 史的理解に到達できるようにするため、日本史 と融合した世界史を、あえて近現代史に絞って 扱掞うとするものである。前近代史は人類の未 来にとって必須の教養とすべき時代と思われ るが、以下の理由によって選択科目の日本史・ 世界史に委ねるように提案する。

近現代史に絞る理由は、第一に、歴史教育 を生きたものにするには、「歴史は暗記科目だ」 という誤解を解く必要があるためである。それ には歴史事象に内在した問題を指摘し、その理 解を促すため、個々の問題の扱いにかなりの時 間を割く必要がある。なお、近現代史のなかで も20世紀に集中して教えるやり方もありうる。

第二に、今までの歴史教育で世界史と日本史 の分断によって生じた弊害を除くためには、世 界史と一体のものとして以外に理解し得ない 近現代史を、重点的に取り上げるのが適切であ る。とりわけ、近現代において日本と近隣地域 の関係がどのように推移したかという知識は、 
未来の国民が近隣国民と健全な関係を築くた めだけでなく、沖縄や北海道など国内の歴史を 弁えるためにも必須である。

第三には、近現代史の知識が公民科など他の 科目を学ぶ上でも有用であるためである。歴史 基礎は 1 年次ないし 2 年次で教えられる可能性 が高く、その具体的な記述は他科目の理解にも 資するにちがいない。

\section{C案：主題編成型}

歴史基礎 2 単位で日本史、世界史の通史を教 えるとすると、中学社会科以下の知識内容を繰 り返すしかない。歴史基礎では高校歴史教育の 目的を明確に設定し、これに適合する主題によ る編成が求められる。現世界史Bは大学受験の 科目としての制約から知識の量を重視してい るため、世界史未履修問題の原因の一つとなっ た。歴史基礎はできうるかぎり人名、特殊な項 目の羅列を避け、歴史の意味の把握に努めるべ きである。

以上の三案はまだ机上の案にとどまってお り、今後さらに、高校で試行的な実験が積み重 ねられ、妥当で実現性のある案に練り上げられ てゆくべきものである。すでに 2010 年 4 月から 「地歴総合」の実験が、2011年4月からは「歴 史基礎」と「地理基礎」の実験が研究開発校で 始まっている。これらの実験結果も含めて、そ の結果が広く共有され、新科目の創設が図られ るよう望んでやまない。

\section{A 案 (時系列型+主題学習型) の簡単な紹介}

先に述べたように、本年 4 月 23 日の公開シン ポでは、A案のみ、しかもその一端を駆足で披 露した。ここではもう少し詳しく紹介したい。 この案を作成するにあたっては、高校の新学習 指導要領を参照しながら、東アジア地域世界を 中心として時代別の構成をとった。また、節単 位で主題学習のテーマを例示した。

全体は 5 章からなる。第 1 章は導入部であり、 「歴史へのいざない」の章名で 2 時間を配当す る。現在に繋がる過去を示す事例を紹介するこ とにより、歴史を学ぶことが現在の生活に大き な関連があること、また現在とは異質な過去の 事例を示すことにより、現在の世界も長い歴史 の一こまである自覚を促す。

第 2 章は原始古代に相当し、「歴史の始まり と地域世界の形成」を教える。ア.世界各地の 農耕文明、牧音文明、都市と国家の形成、イ.南 アジア世界の形成、ウ.東アジア世界の形成と 日本列島社会の位置、の3節からなり、ウ節で は日本を含む東アジア世界と内陸アジア世界 の形成過程を把握させる。全部で 7 時間の時系 列型授業と、それぞれ1時間ずつ（以下同じ） 3 回の主題学習からなる。時系列型授業の精選 の程度は、たとえばギリシャとローマを 1 時間 で終える。また主題学習では「東アジア・東南 アジアに扔ける律令、儒教、漢字文化、仏教の ひろがりについて考えてみよう」（ウ）などを 
配置する。

第3章は中世で、「諸地域世界の交流と再編」 を教える。ア.多様な中世社会の成立、イ、「世 界の一体化」への動きとアジア諸地域の変動、 ウ.南北アメリカ・アフリカ・オセアニア、の 3 節からなる。ア節では宋以前の中国や高麗・日 本で武人の政権が成立したことを把握させる。 7 時間の時系列型授業と、3回の主題学習から なり、主題学習では「ユダヤ教・キリスト教・ イスラーム教三者の関係を考えてみよう」（イ） などを配置する。

第4章は近代で、「諸地域世界の結合と変容」 と銘打ち、ア.ヨーロッパ世界の変容と拡大、 イ.アジア諸地域の繁栄、ウ.日本と世界との結 びつきの強まり、エ.工業化・国民国家の形成 と世界市場の4節で、アジアの繁栄とヨーロッ パの拡大を背景に、諸地域世界の結合が一層進 展するとともに、主権国家体制を整え工業化を 推進したヨーロッパの拡大が、日本を含む東ア ジアに抒いても社会の変容を促したことを理 解させる。

ウ節では東南アジアでの出会い貿易（朱印船 貿易）と日中双方にパイプをもつヨーロッパ勢 力の中継貿易、秀吉の朝鮮侵略と幕藩体制の成 立、海禁政策の一種としての鎖国、日本産銀の 果たした世界史的役割、オランダ東インド会社 からみたドル箱としての日本などを扱う。

本章は 14 時間の時系列型授業と、4回の主題 学習からなる。主題学習では「国民や国境や主 権（対外・対内）という考えはいつごろ成立し
たのか。それ以前はどうなっていたのかを通し て、主権国家成立の意味（前近代国家との違い） を考える。少数民族問題や国境紛争なども考 えてみよう」(ア)、「資本主義の発展による労 働形態の変化（労働時間など）を考える」(エ) などを配置する。

第5章は現代で、「地球規模の歴史の展開」 と題し、ア.帝国主義と社会の変容、イ.二つの 世界大戦とアジア、ウ.東西冷戦・脱植民地化 と経済発展、工.変わりゆく世界と日本、の 4 節からなり、ア節では、欧米や日本における科 学技術の発達、企業・国家の巨大化、国民統合 の進展、帝国主義的な侵略と抗争、一方、そう した欧米や日本に対するアジア・アフリカの複 雑な対応、すなわち中国の義和団のような排外 主義的反発から辛亥革命のような民主共和国 樹立の試みまでの多様な対応を理解させる。

イ節では、総力戦としての二つの世界大戦、 ロシア革命とソヴィエト連邦の成立、アメリカ 合衆国などで始まった大衆社会の形成の意味 ととともに、ファシズムの成立や世界恐慌と資 本主義の変容、アジア・アフリカの民族運動な どを理解させる。その中にあって日本における 政党政治の後退、軍部の台頭が中国への侵略を 拡大し、アジア太平洋戦争に至った過程を理解 させる。

ウ節では、第二次世界大戦後の米ソ両陣営に よる冷戦の展開、戦後の復興と経済発展、アジ ア・アフリカ諸国の独立、平和共存の模索、国 際機関の成長などを理解させる。日本では占領 
期の諸改革と新憲法の制定、講和条約の成立と 高度経済成長による社会の変容を理解させる。

エ節では、市場経済や情報通信のグローバル 化とアジア経済の成長、米中関係の改善と日中 国交正常化、冷戦の終結とソヴィエト連邦の解 体、地域統合の進展と地域紛争の頻発、環境や 資源・エネルギーをめぐる問題などを理解させ、 変わりゆく世界の中における日本の役割につ いて考察させる。

本章は 25 時間の時系列型授業と、5回の主題 学習からなる。ア節では「西欧諸国のアジア進 出に対する日本、中国、朝鮮などアジア諸国の 反応はそれぞれどのような特徵があるか考え てみよう」、イ節では「第一次世界大戦と第二 次世界大戦がその後の歴史に与えた影響の違 いを、国際機関のあり方などに注目して比較し てみよう」ウウ節では「米ソ間の冷戦が日本に 与えた影響について占領期と占領後の変化を 比較しながら考えてみよう」や「ベトナム戦争 が日本をはじめアジア諸国、またアメリカ合衆 国に与えた影響について考えてみよう」、工節 では、「主権国家間の分断・対立の時代から他 国との共生の時代への変化の可能性を、E Uの 成立などを通して考えてみよう」などが配され る。

以上、全体で計 70 時間であるが、公開シン ポジウムでは、教育現場では学校行事などで実 質60時間程度しかとれないという声が出され た。一層の内容の精選が必要となるであろう。 